\title{
Relations among Frequency of Eating alone, Subjective Health Status and Depression in Korean College Students
}

\author{
In-Kyoung Kim ${ }^{1}$, Sang-wook Park ${ }^{2}$ \\ ${ }^{1}$ Department of Nursing, Hanseo University. \\ ${ }^{2}$ (Corresponding author) Division of Educational Evaluation, Korea Institute for \\ Curriculum and Evaluation, OREA \\ swpark@kice.re.kr
}

\begin{abstract}
This study is a descriptive survey study to identify the behavior of the Korean college student's eating alone and to verify the relations among the frequency of eating alone, the subjective health status and the depression. The research subjects were 194 persons. For the analysis method, t-test, ANOVA, Scheffe test, Pearson's correlation coefficient were used. In the results of study, While the frequency of eating alone showed the significant negative correlation with the subjective health status $(r=-.299, p<.001)$ and the significant positive correlation with the depression $(r=.661, p<.001)$, the subjective health status showed the significant negative correlation with the depression ( $r=-.154, p=.033)$. It was observed that the eating alone has correlation with the subjective health status and the depression. The results of this study suggested that the basic data for the development of efficient nursing intervention toward the dietary habit and attitude should be prepared to change the cognition on the eating alone, which may cause the long-term health problem and to maintain the physical and mental health of Korean college students.
\end{abstract}

Keywords: Alone, Depression, Eat, Habit, Health, Student

\section{Introduction}

Due to recent spread of individualistic culture and the increase of single-person household, the social structure is being changed and according to that, the culture of eating alone or drinking alone becomes popular and the interest is being increased. In the results of Statistics Korea's survey[1] single-person households in our country were increased rapidly from $9.0 \%$ in 1990 to $27.1 \%$ in 2015 and expected to occupy more than $1 / 3$ of entire households. In the results of the survey performed with 1,300 college students and the workers in capital region, the percentage of dining one meal a day alone was 30\% although they are not single-person household. and the time taken for dining was 15 minutes, at the most, far less than dining together[2].

In the preceding researches, more than $60 \%$ of the college students eating alone breakfast, lunch and dinner alone and for the reason why they eating alone, 57.8\% were answered that it was hard to arrange the schedule with friends and colleagues, the most and $16.8 \%$ were answered that it was to save the time. In addition, when they have meals as such, as they had the processed food, which they can have quickly, in the convenient places such as convenience

Article history:

Received (February 21, 2019), Review Result (May 12, 2019), Accepted (July 22, 2019) 
store, etc, it is essential to verify the problem of the college student's eating alone and to prepare the countermeasures[3].

The problem of eating alone is that since the people eat roughly causing the health problem, which can be led to the adult diseases, the correction for right dietary habit is required [4][5]. In addition, eating alone has such physical problem but accompanies with mental problem. The subject who eating alone showed depression index higher than the subject who eating together [6][7]. Therefore, investigating the status of the college students' eating alone is deemed to have a meaning.

In the preceding Korean and overseas researches, the contents on the single-person household, especially, the dwelling for elderly and the rupture with society and the nutrient deficiency occupy the most, and the research on the state of eating alone or related problems is not performed almost at all [8][9]. So, this study intended to provide the basic data that are served as the foundation of related program by analyzing the characteristics of college students' eating alone, and the correlation among the frequency of eating alone, the subjective health status and the depression.

\section{Research method}

\subsection{Research design}

This study is a descriptive survey study to identify the behavior of the Korean college student's eating alone and to verify the relations among the frequency of eating alone, the subjective health status and the depression

\subsection{Research subject}

This study selected the subjects randomly from the college students who are attending 3 colleges located in D metropolitan City and Chungcheong-do. Data were collected from March 05, 2-19 to march 30, 2019. This study was performed with the subjects who understood the purpose and intent of this study enough and agreed to participate voluntarily in this study. The number of samples were calculated using G*Power 3.1.4 program[10]. The final research subjects were 194 persons.

\subsection{Research tool}

Data were collected in the manner that the explanation on the research and the information on the consent form were provided to the subject using self-administered questionnaire and the questionnaires filled with answer were collect after distributing them. For the tool of this study, the tool developed, corrected and complemented by researcher based on the preceding research [3], whose contents validity was verified by 3 professors in nursing was used. The tool was composed of total 35 items: 12 items on the general characteristics of the subject and characteristics of eating alone, 2 items for BMI, 1 item for subjective health status and 20 items on depression.

\subsection{Data Analysis}

The collected data were analyzed using SPSS/WIN 20.0 program. For the analysis method, t-test, ANOVA, Scheffe test, Pearson's correlation coefficient was used. 


\section{Research Result}

Table 1. Frequency of Eating alone, Subjective Health Status and Depression related to General Characteristics

\begin{tabular}{|c|c|c|c|c|c|c|c|}
\hline \multirow[b]{2}{*}{$\begin{array}{c}\text { Characteristic } \\
\mathrm{s}\end{array}$} & \multirow[b]{2}{*}{$\begin{array}{c}\text { Categorie } \\
\mathrm{s} \\
\end{array}$} & \multicolumn{2}{|c|}{$\begin{array}{c}\text { Frequency of eating } \\
\text { alone }\end{array}$} & \multicolumn{2}{|c|}{$\begin{array}{l}\text { Subjective health } \\
\text { status }\end{array}$} & \multicolumn{2}{|c|}{ Depression } \\
\hline & & $\mathrm{M} \pm \mathrm{SD}$ & $\begin{array}{l}\mathrm{t} \text { or } \mathrm{F} \\
(p)\end{array}$ & $\mathrm{M} \pm \mathrm{SD}$ & $\begin{array}{l}\mathrm{t} \text { or } \mathrm{F} \\
(p)\end{array}$ & $\mathrm{M} \pm \mathrm{SD}$ & $\begin{array}{l}\mathrm{t} \text { or } \mathrm{F} \\
(p)\end{array}$ \\
\hline \multirow[t]{2}{*}{ Gender } & Female & $\begin{array}{c}3.67 \pm 3.3 \\
6 \\
\end{array}$ & \multirow{2}{*}{$\begin{array}{l}-1.079 \\
(.282)\end{array}$} & $\begin{array}{c}5.62 \pm 6.5 \\
3 \\
\end{array}$ & \multirow{2}{*}{$\begin{array}{c}.685 \\
(.494)\end{array}$} & $\begin{array}{c}47.17 \pm 6 . \\
50\end{array}$ & \multirow{2}{*}{$\begin{array}{c}- \\
1.079 \\
(.282 \\
1\end{array}$} \\
\hline & Male & $\begin{array}{c}4.38 \pm 3.3 \\
7\end{array}$ & & $\begin{array}{c}4.80 \pm 2.7 \\
6\end{array}$ & & $\begin{array}{c}49.25 \pm 7 \\
32\end{array}$ & \\
\hline \multirow[t]{4}{*}{ Grade } & Freshman & $\begin{array}{c}2.88 \pm 2.7 \\
9 \\
\end{array}$ & \multirow{4}{*}{$\begin{array}{l}2.822 \\
(.040)\end{array}$} & $\begin{array}{c}5.43 \pm 2.3 \\
9 \\
\end{array}$ & \multirow{4}{*}{$\begin{array}{c}.560 \\
(.642)\end{array}$} & $\begin{array}{c}48.25 \pm 6 . \\
94\end{array}$ & \multirow{4}{*}{$\begin{array}{c}.615 \\
(.606 \\
)\end{array}$} \\
\hline & $\begin{array}{l}\text { Sophomo } \\
\text { re }\end{array}$ & $\begin{array}{c}4.19 \pm 3.4 \\
7\end{array}$ & & $\begin{array}{c}6.10 \pm 9.8 \\
6\end{array}$ & & $\begin{array}{c}47.53 \pm 6 . \\
25\end{array}$ & \\
\hline & Junior & $\begin{array}{c}4.67 \pm 3.1 \\
9 \\
\end{array}$ & & $\begin{array}{c}5.32 \pm 2.1 \\
7 \\
\end{array}$ & & $\begin{array}{c}46.76 \pm 7 . \\
06\end{array}$ & \\
\hline & Senior & $\begin{array}{c}3.92 \pm 4.2 \\
2\end{array}$ & & $\begin{array}{c}4.30 \pm 2.4 \\
4\end{array}$ & & $\begin{array}{c}46.50 \pm 6 . \\
56\end{array}$ & \\
\hline \multirow[t]{3}{*}{$\begin{array}{l}\text { Type of } \\
\text { housing }\end{array}$} & $\begin{array}{c}\text { Dormitor } \\
y\end{array}$ & $\begin{array}{c}3.11 \pm 3.0 \\
0 \\
\end{array}$ & \multirow{3}{*}{$\begin{array}{l}5.228 \\
(.006)\end{array}$} & $\begin{array}{c}5.78 \pm 2.5 \\
0 \\
\end{array}$ & \multirow{3}{*}{$\begin{array}{c}.670 \\
(.513)\end{array}$} & $\begin{array}{c}48.42 \pm 7 \\
11\end{array}$ & \multirow{3}{*}{$\begin{array}{c}.786 \\
(.457 \\
)\end{array}$} \\
\hline & $\begin{array}{l}\text { boarding } \\
\text { house }\end{array}$ & $\begin{array}{c}4.56 \pm 3.7 \\
6\end{array}$ & & $\begin{array}{c}5.00 \pm 2.2 \\
8 \\
\end{array}$ & & $\begin{array}{c}47.00 \pm 6 . \\
16\end{array}$ & \\
\hline & $\begin{array}{l}\text { House } \\
\text { Living } \\
\text { alone } \\
\end{array}$ & $\begin{array}{c}2.95 \pm 2.4 \\
4\end{array}$ & & $\begin{array}{c}6.20 \pm 11 . \\
95\end{array}$ & & $\begin{array}{c}47.47 \pm 7 \\
16\end{array}$ & \\
\hline \multirow[t]{4}{*}{ Living type } & $\begin{array}{l}\text { Living } \\
\text { alone }\end{array}$ & $\begin{array}{c}5.67 \pm 3.9 \\
4 \\
\end{array}$ & \multirow{4}{*}{$\begin{array}{l}13.149 \\
(<.001)\end{array}$} & $\begin{array}{c}5.23 \pm 2.2 \\
9 \\
\end{array}$ & \multirow{4}{*}{$\begin{array}{c}.529 \\
(.663)\end{array}$} & $\begin{array}{c}46.68 \pm 6 . \\
35\end{array}$ & \multirow{4}{*}{$\begin{array}{c}.989 \\
(.399 \\
)\end{array}$} \\
\hline & $\begin{array}{l}\text { Living } \\
\text { with a } \\
\text { friend }\end{array}$ & $\begin{array}{c}2.75 \pm 2.5 \\
6\end{array}$ & & $\begin{array}{c}5.55 \pm 2.4 \\
9\end{array}$ & & $\begin{array}{c}48.58 \pm 6 . \\
55\end{array}$ & \\
\hline & $\begin{array}{c}\text { Living } \\
\text { with } \\
\text { parents }\end{array}$ & $\begin{array}{c}2.54 \pm 2.0 \\
1\end{array}$ & & $\begin{array}{c}6.37 \pm 12 \\
66\end{array}$ & & $\begin{array}{c}47.02 \pm 7 \\
20\end{array}$ & \\
\hline & Other & $\begin{array}{c}4.04 \pm 3.8 \\
2 \\
\end{array}$ & & $\begin{array}{c}4.45 \pm 2.2 \\
1 \\
\end{array}$ & & $\begin{array}{c}47.42 \pm 6 . \\
93\end{array}$ & \\
\hline \multirow[t]{3}{*}{$\mathrm{BMI}$} & $\begin{array}{c}\text { Underweigh } \\
\mathrm{t}\end{array}$ & $\begin{array}{c}3.09 \pm 2.7 \\
2\end{array}$ & \multirow{3}{*}{$\begin{array}{l}1.043 \\
(.354)\end{array}$} & $\begin{array}{c}9.50 \pm 16 . \\
54\end{array}$ & \multirow{3}{*}{$\begin{array}{c}6.205 \\
(.002) \\
b<a\end{array}$} & $\begin{array}{c}48.36 \pm 6 . \\
09\end{array}$ & \multirow{3}{*}{$\begin{array}{c}.212 \\
(.809 \\
)\end{array}$} \\
\hline & Normal & $\begin{array}{c}3.69 \pm 3.3 \\
3\end{array}$ & & $\begin{array}{c}4.63 \pm 2.5 \\
3\end{array}$ & & $\begin{array}{c}47.34 \pm 6 . \\
18\end{array}$ & \\
\hline & Obesity & $\begin{array}{c}4.23 \pm 3.6 \\
4\end{array}$ & & $\begin{array}{c}5.64 \pm 2.1 \\
4\end{array}$ & & $\begin{array}{c}47.49 \pm 7 . \\
76\end{array}$ & \\
\hline
\end{tabular}




\subsection{General characteristics and Characteristics of Eating Alone}

The average age was 20.00( \pm 3.73$)$. In the gender, female students were $84.0 \%$, the most and for the dwelling pattern, 'boarding house' were $49 \%$, the most. For the cohabitation type, 'Living with a friend' was $35.1 \%$, the most. For the BMI, normal was $58.5 \%$, the most, obese was $35.1 \%$.The score of subjective health status was 5.49( \pm 6.09$)$ points.

Table 2. Frequency of Eating Alone, Subjective Health Status and Depression related to Characteristics of Eating Alone

\begin{tabular}{|c|c|c|c|c|c|c|c|}
\hline \multirow[b]{2}{*}{ Characteristics } & \multirow[b]{2}{*}{ Categories } & \multicolumn{2}{|c|}{$\begin{array}{c}\text { Frequency of eating } \\
\text { alone }\end{array}$} & \multicolumn{2}{|c|}{$\begin{array}{c}\text { Subjective health } \\
\text { status }\end{array}$} & \multicolumn{2}{|c|}{ Depression } \\
\hline & & $\mathrm{M} \pm \mathrm{SD}$ & $\begin{array}{l}\text { tor } \mathrm{F} \\
(p)\end{array}$ & $\mathrm{M} \pm \mathrm{SD}$ & $\begin{array}{l}\text { tor } \mathrm{F} \\
(p)\end{array}$ & tor $F$ & \\
\hline \multirow[t]{3}{*}{$\begin{array}{l}\text { Spontaneity of } \\
\text { eating alone }\end{array}$} & Not at all & $\begin{array}{c}3.06 \pm 3.5 \\
7 \\
\end{array}$ & \multirow{3}{*}{$\begin{array}{l}.458 \\
(.633)\end{array}$} & $\begin{array}{c}5.56 \pm 2.5 \\
3 \\
\end{array}$ & \multirow{3}{*}{$\begin{array}{l}.152 \\
(.859)\end{array}$} & $\begin{array}{c}48.24 \pm 6 . \\
43\end{array}$ & \multirow{3}{*}{$\begin{array}{l}.458 \\
(.633)\end{array}$} \\
\hline & Just so & $\begin{array}{c}3.95 \pm 3.3 \\
6 \\
\end{array}$ & & $\begin{array}{c}5.59 \pm 7.4 \\
6 \\
\end{array}$ & & $\begin{array}{c}47.17 \pm 6 . \\
51\end{array}$ & \\
\hline & Very well & $\begin{array}{c}4.50 \pm 2.7 \\
3 \\
\end{array}$ & & $\begin{array}{c}4.81 \pm 2.1 \\
9 \\
\end{array}$ & & $\begin{array}{c}47.68 \pm 8 . \\
06\end{array}$ & \\
\hline \multirow[t]{3}{*}{$\begin{array}{l}\text { Cost on eating } \\
\text { alone (won) }\end{array}$} & $\begin{array}{l}\text { Less than } \\
5,000\end{array}$ & $\begin{array}{c}4.34 \pm 3.9 \\
7 \\
\end{array}$ & \multirow{3}{*}{$\begin{array}{l}2.040 \\
(.133)\end{array}$} & $\begin{array}{c}5.24 \pm 2.2 \\
3 \\
\end{array}$ & \multirow{3}{*}{$\begin{array}{c}.439 \\
(.645)\end{array}$} & $\begin{array}{c}48.34 \pm 5 . \\
40\end{array}$ & \multirow{3}{*}{$\begin{array}{l}1.735 \\
(.179)\end{array}$} \\
\hline & $\begin{array}{l}\text { Less than } \\
7,000\end{array}$ & $\begin{array}{c}3.40 \pm 2.7 \\
9\end{array}$ & & $\begin{array}{c}6.04 \pm 9.7 \\
2 \\
\end{array}$ & & $\begin{array}{c}46.34 \pm 7 . \\
08\end{array}$ & \\
\hline & $\begin{array}{l}\text { Less than } \\
10,000\end{array}$ & $\begin{array}{c}3.30 \pm 2.7 \\
8 \\
\end{array}$ & & $\begin{array}{c}5.09 \pm 2.6 \\
5 \\
\end{array}$ & & $\begin{array}{c}47.78 \pm 7 . \\
96\end{array}$ & \\
\hline \multirow[t]{3}{*}{$\begin{array}{l}\text { Behavior when } \\
\text { eating alone }\end{array}$} & Focus on food & $\begin{array}{c}3.91 \pm 3.5 \\
7\end{array}$ & \multirow{3}{*}{$\begin{array}{l}5.474 \\
(.001)\end{array}$} & $\begin{array}{c}5.65 \pm 7.9 \\
6 \\
\end{array}$ & \multirow{3}{*}{$\begin{array}{l}3.437 \\
(.018)\end{array}$} & $\begin{array}{c}47.38 \pm 7 . \\
41\end{array}$ & \multirow{3}{*}{$\begin{array}{l}.049 \\
(.952)\end{array}$} \\
\hline & $\begin{array}{c}\text { Phone, } \\
\text { message, SNS }\end{array}$ & $\begin{array}{c}2.77 \pm 3.5 \\
6 \\
\end{array}$ & & $\begin{array}{c}5.53 \pm 2.6 \\
1 \\
\end{array}$ & & $\begin{array}{c}47.77 \pm 7 . \\
50 \\
\end{array}$ & \\
\hline & $\begin{array}{c}\text { Watching TV, } \\
\text { internet, } \\
\text { games } \\
\end{array}$ & $\begin{array}{c}4.17 \pm 3.1 \\
2\end{array}$ & & $\begin{array}{c}5.08 \pm 2.7 \\
2\end{array}$ & & $\begin{array}{c}47.44 \pm 5 . \\
98\end{array}$ & \\
\hline \multirow[t]{3}{*}{$\begin{array}{c}\text { Place of eating } \\
\text { alone }\end{array}$} & House & $\begin{array}{c}2.63 \pm 2.5 \\
6 \\
\end{array}$ & \multirow{3}{*}{$\begin{array}{l}50.692 \\
(<.001) \\
a<b<c\end{array}$} & $\begin{array}{c}4.96 \pm 2.5 \\
3 \\
\end{array}$ & \multirow{3}{*}{$\begin{array}{l}2.322 \\
(.101)\end{array}$} & $\begin{array}{c}48.57 \pm 6 . \\
09 \\
\end{array}$ & \multirow{3}{*}{$\begin{array}{c}5.035 \\
(.007) \\
c<a\end{array}$} \\
\hline & $\begin{array}{c}\text { Convenience } \\
\text { store }\end{array}$ & $\begin{array}{c}4.48 \pm 2.0 \\
2 \\
\end{array}$ & & $\begin{array}{c}7.29 \pm 12 . \\
28 \\
\end{array}$ & & $\begin{array}{c}45.48 \pm 6 . \\
73\end{array}$ & \\
\hline & Restaurants & $\begin{array}{c}8.56 \pm 4.2 \\
4\end{array}$ & & $\begin{array}{c}5.28 \pm 2.4 \\
9\end{array}$ & & $\begin{array}{c}45.29 \pm 8 . \\
28\end{array}$ & \\
\hline
\end{tabular}

\subsection{Frequency of Eating alone, Subjective Health Status and Depression related to General Characteristics}

The frequency of eating alone, subjective health status and the depression according to the general characteristics of the subject are as shown in Table 1 . The frequency of eating aloneshowed the significant difference according to grade $(\mathrm{F}=2.822, p=.040)$, dwelling pattern ( $\mathrm{F}=5.288, p=.006)$, and cohabitation type $(\mathrm{F}=13.149, p<.001)$. The subjective health status showed the significant difference according to BMI $(\mathrm{F}=6.205, p=.002)$ The depression did not show the significant difference according to the gender, grade, dwelling pattern, cohabitation type and the BMI. 


\subsection{Frequency of Eating Alone, Subjective Health Status and Depression related to Characteristics of Eating alone}

The relations among the frequency of eating alone, subjective health status and the depression related to subject's characteristics of eating alone are as shown in Table 2. The frequency of eating alone showed the significant difference according to the behavior when eating alone ( $\mathrm{F}=5.474, p<.001)$ and the place of eating alone $(\mathrm{F}=50.692, p<.001)$. In addition, the subjective health status showed the significant difference according to the behavior when dining along ( $\mathrm{F}=3.437, p=.018)$. Depression showed the significant difference according to the place of eating alone $(\mathrm{F}=5.035, p=.007)$.

\subsection{Correlation among Frequency of eating alone, Subjective Health Status and Depression}

Since the subjective health status showed the statistically significant negative correlation with the depression ( $\mathrm{r}=-.154, \mathrm{p}=.033$ ), it was shown that the higher the subjective health status, the lower the depression. Since the frequency of eating alone and the depression showed the positive correlation ( $\mathrm{r}=.661, \mathrm{p}<.001)$, it was shown that the higher the frequency of eating alone, the higher the depression.

Table 3. Correlation among frequency of Eating Alone, Subjective Health Status, Depression

\begin{tabular}{|c|c|c|c|}
\hline & $\begin{array}{c}\text { Frequency of } \\
\text { eating alone }\end{array}$ & $\begin{array}{c}\text { Subjective health } \\
\text { status }\end{array}$ & Depression \\
\hline $\begin{array}{c}\text { Frequency of } \\
\text { eating alone }\end{array}$ & 1 & & \\
\hline $\begin{array}{c}\text { Subjective health } \\
\text { status }\end{array}$ & $-.299(<.001)$ & 1 & $-.154(.033)$ \\
\hline Depression & $.661(<.001)$ & $.773(<.001)$ & 1 \\
\hline
\end{tabular}

\section{Discussion and Conclusion}

In this study, the status for the behavior of eating alone was identified from the Korean college students and the correlation among the frequency of eating alone, subjective health status and the depression was identified.

In summary of the results, the frequency of Korean college student's eating alone was average 5 times a week and the grades having many major study class showed the higher frequency. And the student who live cooking by himself and the student who lives alone showed the higher frequency. In addition, it was shown that the student of watching TV, using internet and playing the game while eating alone were a lot and mostly eating alone at home. Particularly, the depression score of the student who eating alone at home was higher than the student who eating outside. In addition, the students who watch TV or use internet or play game perceived the subjective health status as low. In many preceding researches showed the results that the health status of those who eating alone was not good [4][5] and particularly, since they have physical and mental problems such as obesity, diabetes, hypertension, depression, etc [11], it is deemed that the countermeasures are needed for that. Since that the subject who eating alone every meal has high risk of metabolic syndrome and the high proportion of depression was reported by other researches demanding the countermeasures [12]. In the results of this 
study, the perception on eating alone, which can cause the long-term health problems, needs to be changed and the basic data for efficient nursing intervention development toward the dietary habit and attitude should be prepared to maintain the physical and mental health of the Korean college students. This study has limitation in taking the college students of some region as subjects and to generalize the results of this study, the subjects need to be expanded to diverse regions.

\section{References}

[1] Statistics Korea. 2010 Social Survey Results. http://www.kostat.go.kr/portal/korea/kor_nw/2/6/1/index. June 25,(2013)

[2] KBS News. 'Eating alone' makes obesity. Fromnutritional imbalance to adult disease. http://news.kbs.co.kr/news/ view.do?ncd=3292439,(2016)

[3] B. B. Choi. "Recognition and Consumption of Meal Alone and Processed Food according to Major of College Students”. The Korean Society of Food and Nutrition, (2016), Vol.29, No.6, pp.911-922, DOI: 10.9799/ksfan.2016.29.6.911

[4] Y. J. Oh. Conference proceeding. "The increase of One-person households rate and nutrition and eating behavior of alone meal”. The Korean society of Community Nutrition,(2016)

[5] J. S. Park, J. J. Lee, H. S. Oh, H. H. Lim. "The Characteristics in Obesity Classification Group of College Student by Analyzing Their BMI and Blood Test and the Association between Factors Contributing to Obesity and Obesity according to BMI”. Journal of medicine rehabilitation, (2014),Vol.27, No.4, pp.61-70,

[6] Wang et al. "Association between eating alone and depressive symptom in elders: a cross-sectional study". BMC Geriatrics, (2016), Vol.16, No.19. DOI:10.1186/s12877-016-0197-2

[7] The Hankyoreh Newspaper. 'Eat alone today' Men who eat alone eat 2.4 times the risk of depression. www.hani.co.kr/arti/PRINT/ 750329.html,(2016)

[8] E. N. Kang, M. H. Lee. "Single-person households in South Korea and their policy implications.” Health and Welfare Forum, (2017), Vol. 4, pp.47-56,

[9] Y. O. Kim. “A study on single person households in Korea”. Korean Journal of Family Social Work, (2016),Vol.52, pp.139-166

[10] Faul, F., Erdfelder, E., Buchner, A., \& Lang, A. G. "Statistical power analyses using G*Power 3.1: tests for correlation and regression analyses”. Behav Res Methods, (2009),Vol.41, No.4, pp.1149-1160 DOI: 10.3758/BRM.41.4.1149

[11] H. S. Ryu, M.A. Lee. "Eating alone and depressive symptoms of Korean older adults: Examining differential effects by gender”. Survey Research. (2017), Vol.20, No.1. pp.1-27

[12] A. R. Kim. "Effect of health behaviors, dietary habits, and psychological health on metabolic syndrome in oneperson households among Korean young adults”. Journal of Digital Convergence. (2018), Vol.16. No.7, pp.493-509, DOI: 10.14400/JDC.2018.16.7.493 